\title{
Visualisasi Aliran Udara pada Kotak Konveksi Udara Menggunakan Adaptive Finite Element Method
}

\author{
Sayahdin Alfat ${ }^{* 1}$, Abdin $^{1}$, Rosliana Eso ${ }^{1}$ \\ ${ }^{1}$ Jurusan Pendidikan Fisika, Universitas Halu Oleo, Jl. H.E.A Mokodompit Kendari \\ 93232, Sulawesi Tenggara, Indonesia \\ * Corresponding author. E-mail: sayahdin.alfat@uho.ac.id, \\ Telp: $+62-8541876994$
}

\begin{abstract}
ABSTRAK
Peristiwa aliran udara pada kotak konveksi menjadi penting untuk dipahami. Selain metode eksperimen, metode numerik menjadi salah satu pendekatan yang realistis dan mudah serta murah. Secara garis besar, studi ini akan menampilkan transfer panas dan aliran udara pada kotak konveksi menggunakan Adaptive Finite Element Method dan profil temperatur serta kecepatan udara di beberapa titik pada kotak konveksi. Simulasi ini mengadaptasi persamaan Rayleigh-Benard sebagai persamaan pembentuk aliran dan Metode Karakteristik sebagai metode diskritiasi waktu. Secara keseluruhan, penentuan solusi numerik berupa transfer panas dan aliran fluida menggunakan FreeFEM++. Parameter waktu yang digunakan selama perhitungan, seperti; $\Delta t=10^{-3}$ dan $t_{\max }=10^{3}$. Beberapa hal yang menjadi catatan dari penelitian ini sebagai berikut; (1) profil temperatur berbeda di setiap titik pada kotak konveksi, temperatur tertinggi dijumpai di sekitar sumber panas sebesar $100^{\circ} \mathrm{C}$ dan terendah berada di permukaan ujung tabung yakni $20^{\circ} \mathrm{C}$. (2) Aliran udara masuk melalui sisi kiri tabung dan ke luar melalui sisi lainnya. Ini menyebabkan kecepatan rata-rata di kedua tabung tersebut sama dan bernilai $\overline{\mathrm{u}}_{\mathrm{y}} \approx 10.2$ pada saat $t \geq 0.06$.
\end{abstract}

Kata Kunci : Aliran Udara; Adaptive Finite Element Method; Persamaan Rayleigh-Benard; Kotak Konveksi 


\begin{abstract}
Air flows phenomena on the box convection become important to be realized. Besides the experiment, the numerical method has become a realistic technique, easy and cheap. Generally, the study would show the heat transfer and air flows on the box convection using the Adaptive Finite Element Method. On the other hand, the profile of temperature and air velocity in some points on the box convection would be also shown. The simulation adapted Rayleigh-Benard Equation as the governing equation and the characteristic Method as the time discretization method. Overall, the numerical solution of heat transfer and air flows was solved by FreeFEM++. The time parameters used during the simulation are $\Delta t=10^{-3}$ and $t_{\max }=$ $10^{3}$. Based on the study, there were some summaries as follows; (1) the temperature profile was different at each point in the convection box, the highest temperature was found around the heat source which was $100^{\circ} \mathrm{C}$, and the lowest was at the end of the tube, namely $20^{\circ} \mathrm{C}$. (2) The air flowed in through the left side of the tube and flowed out through the other side. The consequence was the same average velocity in both tubes and its value fulfilled $\overline{\mathrm{u}}_{\mathrm{y}} \approx 10.2$ when $t \geq 0.06$.
\end{abstract}

Keywords: Air Flows; Adaptive Finite Element Method; Rayleigh-Benard Equation; Box Convection

\section{Pendahuluan}

Peristiwa aliran udara merupakan fenomena yang biasa namun juga sangat kompleks untuk dipelajari [1]. Hal ini karena fenomena tersebut melibatkan banyak faktor, seperti; topografi muka bumi atau bentang alam dan medan [2][4], dan juga temperatur [1], [5]. Karenanya itu, salah satu eksperimen sederhana yang digunakan dan dapat menjelaskan peristiwa aliran udara adalah pemanfaatan alat konveksi udara (gases apparatus convection box) [6], [7]. Ilustrasi alat konveksi dapat dilihat pada Gambar 1. Secara visualisasi, alat ini sangat cocok untuk mengamati proses terjadinya aliran udara, namun untuk mengamati secara mendalam atau spesifik beberapa parameter-parameter lain, seperti; distribusi temperatur, fluktuasi kecepatan aliran udara dan distribusi tekanan, dibutuhkan perangkat tambahan, berupa alat ukur ataupun sensor. Tentu, penambahan tersebut tidak dengan mudah dilakukan, ini karena alat-alat ukur tersebut harus presisi dan juga cocok atau competibel untuk alat tersebut. 
Sisi lainnya, dengan penambahan alat ukur berkonsekuensi pada biaya penelitian yang semakin besar. Hal inilah yang kemudian menjadi kendala atau masalah pada alat ini. Jika aliran udara dapat dinyatakan dalam bentuk sistem diferensial parsial atau partial differential equation-PDE yang bergantung terhadap kecepatan udara $(v)$ dan temperatur $(T)$ maka metode numerik merupakan salah satu metode yang cocok untuk menyelesaikan fenomena ini [8].

Kehadiran metode numerik sebagai salah satu cara untuk memvisualisasikan proses aliran udara menjadi sangat realistis. Sisi lainnya, metode ini dapat memotret dan mencatat parameter-parameter lain, seperti; distribusi temperatur dan tekanan, dan juga fluktuasi kecepatan aliran udara, yang bekerja dalam proses aliran udara [9], [10]. Metode ini bukanlah merupakan metode baru, metode ini berkembang seiring dengan perkembangan teknologi komputasi. Berbagai varians metode numerik dengan fokus penelitian aliran udara sudah sering dilakukan oleh beberapa peneliti selumnya, seperti; Metode Beda Hingga (Finite Different Method-FDM) [10][12], Metode Elemen Hingga (Finite Element Method-FEM) [8], [12]-[14], Computational Fluid Dynamics (CFD) [9], [15], Metode Volume Hingga (Finite Volume Method-FVM) [13] dan Lattice Boltzmann Method-FBM [16].

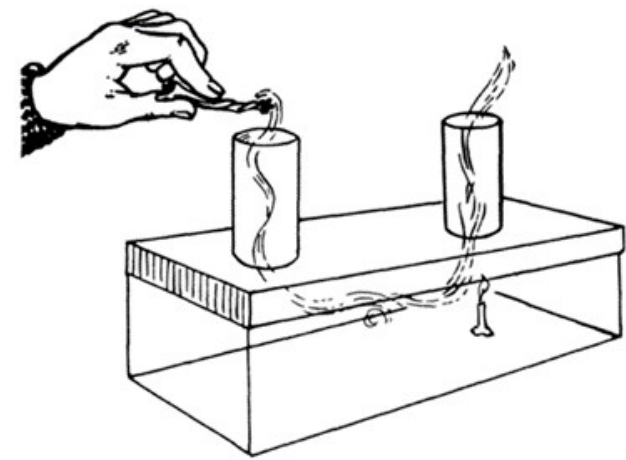

Gambar 1. Tabung kotak konveksi [17]

Salah satu metode di atas, Metode Elemen Hingga merupakan metode numerik yang perkembangannya sangat dinamis, metode ini menawarkan kemudahan pembentukan grid pada domain-domain yang kompleks. Pada sisi lain untuk varians FEM, seperti; Adaptive Finite Element Method (AFEM), ini dipandang akurat [18]-[20], efisien [21] dan stabil [19], serta juga dapat mempersingkat waktu perhitungan [22]. Mengacu pada hal-hal tersebut, penulis memandang perlu melakukan penelitian mengenai investigasi numerik terhadap pola atau perilaku aliran udara pada kotak konveksi udara secara 2 dimensi menggunakan AFEM.

Secara garis besar, artikel ini akan berfokus pada visualisasi aliran udara akibat proses perubahan dan perbedaan temperatur dalam sistem 2 dimensi. Merujuk hal itu, kombinasi persamaan aliran fluida dan transfer panas atau persamaan Rayleigh-Benard menjadi persamaan ideal untuk menyelesaikan kasus tersebut [8], [23]. Sebagai tambahan, profil temperatur, dan fluktuasi 
kecepatan aliran udara di beberapa titik dan juga nilai rata-rata perubahan temperatur akan ditampilkan. Artikel ini disusun atas empat bagian, yakni; Pendahuluan, yang sudah dijelaskan pada bagian ini. Desain dan Metode Komputasi, bagian ini akan menjelaskan beberapa hal, yakni; persamaan Rayleigh-Benard, ilustrasi desain domain dan tentunya yakni AFEM. Hasil dan Pembahasan, hasil-hasil numerik dan penjelasan mengenai proses aliran udara akan ditampilkan di bagian ini. Terakhir, bagian Penutup akan mengungkapkan ringkasan penelitian ini secara spesifik.

\section{Desain dan Metode Komputasi}

\subsection{Persamaan umum}

Pada dasarnya, aliran udara dapat diungkapkan melalui persamaan Navier -Stokes [10]. Akan tetapi, penggunaan persamaan tersebut untuk melihat pengaruh perubahan dan perbedaan temperatur pada proses aliran udara tidak cocok. Olehnya itu, dibutuhkan adanya persamaan tambahan yakni persamaan transfer panas. Kedua sistem persamaan tersebut yakni Sistem Persamaan Rayleigh-Benard [8], [23].

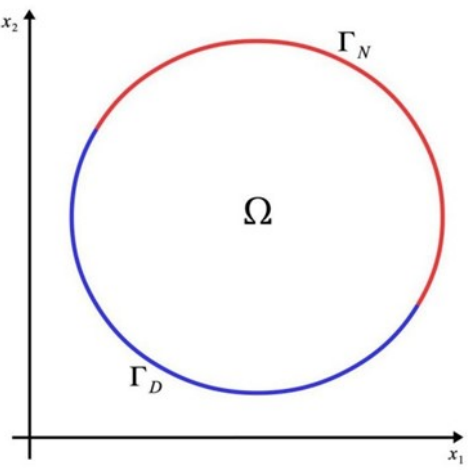

Gambar 2. Illustrasi domain pada system

Anggap domain $(\Omega)$ berada pada system koordinat Kartesius dalam dua dimensi $\left[x_{1}\right.$, $x_{2}$ ] dengan permukaan domain memiliki kondisi batas Dirichlet $\left(\Gamma_{\mathrm{D}}\right)$ dan Neumann $\left(\Gamma_{\mathrm{N}}\right)$ (lihat Gambar 2).

Dengan begitu Sistem Persamaan RayleighBenard dapat dituliskan seperti persamaan (1). dimana $\boldsymbol{x}=\left[\boldsymbol{x}_{1}, \boldsymbol{x}_{2}\right], \boldsymbol{u}=\left[\boldsymbol{u}_{1}, \boldsymbol{u}_{2}\right], p, T, t$, dan $g$ secara berturut-turut mewakili vektor posisi $[\mathrm{m}]$, vektor kecepatan $[\mathrm{m} / \mathrm{s}]$, tekanan $[\mathrm{Pa}]$, temperatur udara $[\mathrm{K}]$, waktu $[\mathrm{s}]$, dan percepatan gravitasi $\left[\mathrm{ms}^{-2}\right]$. Adapun $\mathrm{v}, \rho_{0}, T_{0}$ dan $\kappa$ masing-masing mewakili viskositas kinematik $\left[\mathrm{m}^{2} / \mathrm{s}\right]$, konstanta positif suatu massa jenis $\left[\mathrm{kg} / \mathrm{m}^{3}\right]$, temperatur awal $[\mathrm{K}]$ dan difusivitas panas $\left[\mathrm{m}^{2} / \mathrm{s}\right]$. Persamaan (1), baris pertama merupakan Persamaan Navier -Stokes, baris kedua adalah konservasi massa atau persamaan kontinuitas, dan baris ketiga menjelaskan persamaan aliran panas secara konveksi.

$$
\left\{\begin{array}{cc}
\left(\frac{\partial \boldsymbol{u}}{\partial t}+\boldsymbol{u} \cdot \boldsymbol{\nabla u}\right)=-\frac{1}{\rho_{0}} \boldsymbol{\nabla} p+\vartheta \boldsymbol{\nabla}^{2} \boldsymbol{u}-\boldsymbol{\alpha}\left(\boldsymbol{T}-\boldsymbol{T}_{\mathbf{0}}\right) g \hat{x}_{2} & x=\left[x_{1}, x_{2}\right] \in \Omega \\
\boldsymbol{\nabla} \cdot \boldsymbol{u}=0 & x=\left[x_{1}, x_{2}\right] \in \Omega \\
\left(\frac{\partial T}{\partial t}+\boldsymbol{u} \cdot \boldsymbol{\nabla} T\right)=\kappa \boldsymbol{\nabla}^{2} T & x=\left[x_{1}, x_{2}\right] \in \Omega
\end{array}\right.
$$


Adapun syarat batas dan kondisi awal untuk Persamaan (1) memenuhi persamaan (2) dan (3) :

Syarat Batas:

$$
\left\{\begin{array}{cc}
\boldsymbol{u}(x)=g_{1}(x) & \text { Pada } \Gamma_{D} \\
\frac{\partial \boldsymbol{u}}{\partial n}=q_{1}(x) & \text { Pada } \Gamma_{N} \\
T(x)=g_{2}(x) & \text { Pada } \Gamma_{D} \\
\kappa \frac{\partial T}{\partial n}=q_{2}(x) & \text { Pada } \Gamma_{N}
\end{array}\right.
$$

Syarat Awal:

$$
\left\{\begin{array}{cc}
u(x, t=0)=u_{0} & \text { Pada } \Omega \\
T(x, t=0)=T_{0} & \text { Pada } \Omega
\end{array}\right.
$$

Karena pelibatan metode grid, olehnya itu, persamaan di atas bukan merupakan persamaan akhir (the final equation). Disini, penggunaan bilangan tak berdimensi (dimensionless number) di Persamaan (1) akan menjadi penting. Misalkan variabel-variabel tak berdimensi seperti $t^{*}, x^{*}, u^{*}, T^{*}$, dan $\mathrm{p}^{*}$, didefenisikan sebagai persamaan (4), (5), dan (6) berikut

$$
\begin{aligned}
t^{*} & :=\frac{U_{R}}{L_{R}} t, \quad x^{*}:=\frac{x}{L_{R}} \\
\boldsymbol{u}^{*} & :=\frac{\boldsymbol{u}}{U_{R}}, \quad p^{*}:=\frac{\kappa}{\rho_{0} U_{R}^{2} \vartheta} p \\
T^{*} & :=\frac{T-T_{0}}{\Delta T}
\end{aligned}
$$

dengan $L_{R}, U_{R}$, dan $\Delta T$ secara berturutturut merupakan suatu konstanta untuk panjang $[\mathrm{m}]$, kecepatan $[\mathrm{m} / \mathrm{s}]$, temperatur $[\mathrm{K}]$. Mengacu pada

Persamaan (4) (6), Persamaan (1) dapat dibentuk sebagai persamaan (7).

Dengan Bilangan Rayleigh ( $\mathrm{Ra})$ dan Bilangan Prandlt (Pr) didefenisikan $R a=\frac{\alpha g \Delta T L_{R}{ }^{3}}{\vartheta \kappa}$ dan $\operatorname{Pr}=\frac{\vartheta}{\kappa}$.

\subsection{Asumsi dan Desain Komputasi}

Untuk memudahkan proses perhitungan proses aliran udara secara komputasi, maka pada bagian ini akan diperkenalkan beberapa asumsi atau pendekatan yakni sebagai berikut:

a. Simulasi dilaksanakan dalam tinjauan sistem koordinat Kartesius 2D.

b. Kecepatan awal udara di dalam kotak konveksi homogen dan bernilai nol, atau $u^{*}(x, 0)=0$.

c. Temperatur awal udara dalam kotak konveksi seragama yang memenuhi $\mathrm{T}^{*}(x, 0)=20$.

d. Fluida yang digunakan bersifat fluida termanpatkan (compresible fluid).

e. Sumber panas $f$ diabaikan atau bernilai nol. Secara matematis, itu dapat dituliskan $f^{*}(x, t)=0$.

f. Tidak ada interaksi panas pada dinding-dinding kotak konveksi.

$$
\left\{\begin{array}{rlrl}
\frac{1}{\operatorname{Pr}}\left(\frac{\partial \boldsymbol{u}^{*}}{\partial t^{*}}+\boldsymbol{u}^{*} \cdot \boldsymbol{\nabla}^{*} \boldsymbol{u}^{*}\right) & =-\boldsymbol{\nabla}^{*} p^{*}+\boldsymbol{\nabla}^{* 2} \boldsymbol{u}^{*}-\boldsymbol{R} \boldsymbol{a} T^{*} \hat{x}_{2} & & x^{*}=\left[x_{1}^{*}, x_{2}^{*}\right] \in \Omega \\
\boldsymbol{\nabla}^{*} \cdot \boldsymbol{u}^{*}=0 & x^{*}=\left[x_{1}^{*}, x_{2}^{*}\right] \in \Omega \\
\left(\frac{\partial T^{*}}{\partial t^{*}}+\boldsymbol{u}^{*} \cdot \boldsymbol{\nabla}^{*} T^{*}\right)=\frac{1}{\sqrt{\operatorname{RaPr}}} \boldsymbol{\nabla}^{* 2} T^{*} & x^{*}=\left[x_{1}^{*}, x_{2}^{*}\right] \in \Omega
\end{array}\right.
$$


Namun, interaksi terjadi hanya pada lubang kotak konveksi.

$$
\frac{\partial T^{*}}{\partial n}=\left\{\begin{array}{cl}
0 & \text { semua dinding } \\
q(x) & \text { pada lubang }
\end{array}\right.
$$

g. Temperatur sumber yang diberikan berasal dari salah satu dinding bernilai:

$$
T^{*}(x, t)=g(x) \quad \text { dinding } 2
$$

g. Proses keluar-masuk udara (inflowoutflow) hanya terjadi pada lubang kotak konveksi. Sedangkan, proses slip terjadi saat udara menabrak dinding kotak, secara matematis dapat dituliskan:

$$
\begin{cases}\boldsymbol{u}^{*}=\text { unknown } & \text { lubang } \\ u_{1}=0 & \text { dind. vert. } \\ u_{2}=0 & \text { dind. horiz. }\end{cases}
$$

Asumsi-asumsi di atas tersebut dapat diilustrasikan seperti Gambar 3.

Disini, seluruh dimensi pada domain komputasi, Gambar 3, adalah sistem skala tak-berdimensi (non-dimensional), artinya parameter-parameter ruang, seperti; panjang, lebar, dan tinggi, tidak lagi berskala meter $[m]$ akan tetapi tak berskala [-]. Untuk besar masing-masing parameter ruang pada kotak dapat dilihat melalui Tabel 1:

Tabel 1. Parameter tabung konveksi

\begin{tabular}{lcc}
\hline Parameter & Besar & Unit \\
\hline Panjang kotak $(L)$ & 0.2 & {$[-]$} \\
\hline Tinggi kotak $(H)$ & 0.075 & {$[-]$} \\
\hline Dia. lubang kotak & 0.03 & {$[-]$} \\
\hline Jarak antar lubang $\left(l_{3}\right)$ & 0.1 & {$[-]$} \\
\hline Jarak ujung kotak dan & 0.02 & {$[-]$} \\
lubang $\left(l_{1}\right.$ atau $\left.l_{5}\right)$ & & \\
\hline Dia. sumber panas & 0.014 & {$[-]$} \\
\hline Tinggi sumber panas & 0.0187 & {$[-]$} \\
\hline Tinggi tabung $(h)$ & 0.065 & {$[-]$} \\
\hline
\end{tabular}

\subsection{Adaptive Finite Element Method}

Pada bagian ini akan dijelaskan mengenai metode numerik yang digunakan untuk memvisualisasikan fenomena aliran udara pada kotak konveksi. Metode numerik yang digunakan dalam menyelesaikan
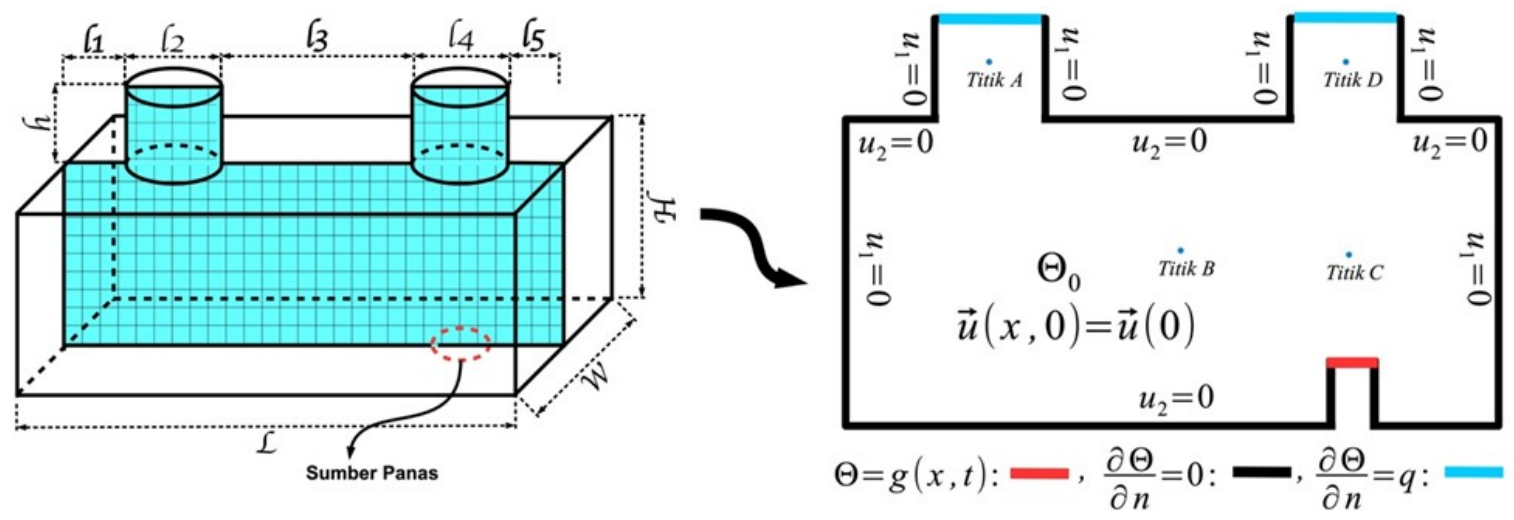

Gambar 3. Domain komputasi; ilustrasi 3D (kiri) dan penyederhanaan pada sistem 2D (kanan). Dinding biru dianggap sebagai lubang kotak konveksi, sedangkan dinding berwarna hitam dan merah masing-masing mewakili diding 1 dan 2. 
Persamaan (7) yakni AFEM, metode ini akan mengupdate jumlah mesh dalam setiap pertambahan waktu. Disini, update jumlah mesh didasarkan pada kecepatan dan temperatur fluida (udara). Adapun software yang digunakan adalah FreeFEM++ [24], dengan tipe element mesh yang dipergunakan adalah adaptive P2-element.

\subsection{Diskritisasi Waktu}

Langkah pertama yang dilakukan untuk menyelesaikan sistem Persamaan (7) adalah melakukan semi diskritisasi dalam waktu menggunakan Metode Karakteristik [8]. Kedua, jika nilai $u^{k}(\mathrm{x})$ dan $T^{k}(\mathrm{x})$ merupakan pendekatan dari $u$ dan $T$ pada waktu, $t=k \Delta t$, $(k=0,1,2, \ldots)$ maka nilai $u^{k}$ dan $T^{k}$ dapat diselesaikan dengan menggunakan skema implisit dari persamaan (7) sehingga diperoleh persamaan (11).

$$
\begin{array}{cl}
\frac{1}{\operatorname{Pr}}\left(\frac{\boldsymbol{u}^{k+1}-\boldsymbol{u}^{k} \circ \boldsymbol{X}^{k}}{\Delta t}, v\right)+a_{0}\left(\boldsymbol{u}^{k+1}, v\right)+b\left(v, p^{k+1}\right)=R a\left(T^{k} \hat{\boldsymbol{x}}_{2}, v\right) & \forall v \in V \\
b\left(\boldsymbol{u}^{k+1}, q\right)=0 & \forall q \in Q \\
\left(\frac{T^{k+1}-T^{k} \circ \boldsymbol{X}^{k}}{\Delta t}, \psi\right)+c_{0}\left(T^{k+1}, \psi\right)=0 & \forall \psi \in \Psi_{0}
\end{array}
$$

Dengan $\quad a_{0}\left(\boldsymbol{u}^{k+1}, v\right)=\nabla u^{k+1} \cdot \nabla \mathrm{v}$, $b\left(v, p^{k+1}\right)=-\nabla \cdot v p^{k+1}, \quad$ dan $\quad$ juga $c_{0}\left(T^{k+1}, \psi\right)=\nabla T^{k+1} \cdot \nabla \psi$.

\subsection{Diagram Alir Perhitungan}

Adapun proses perhitungan secara numerik dapat dilihat melalui Gambar 4.
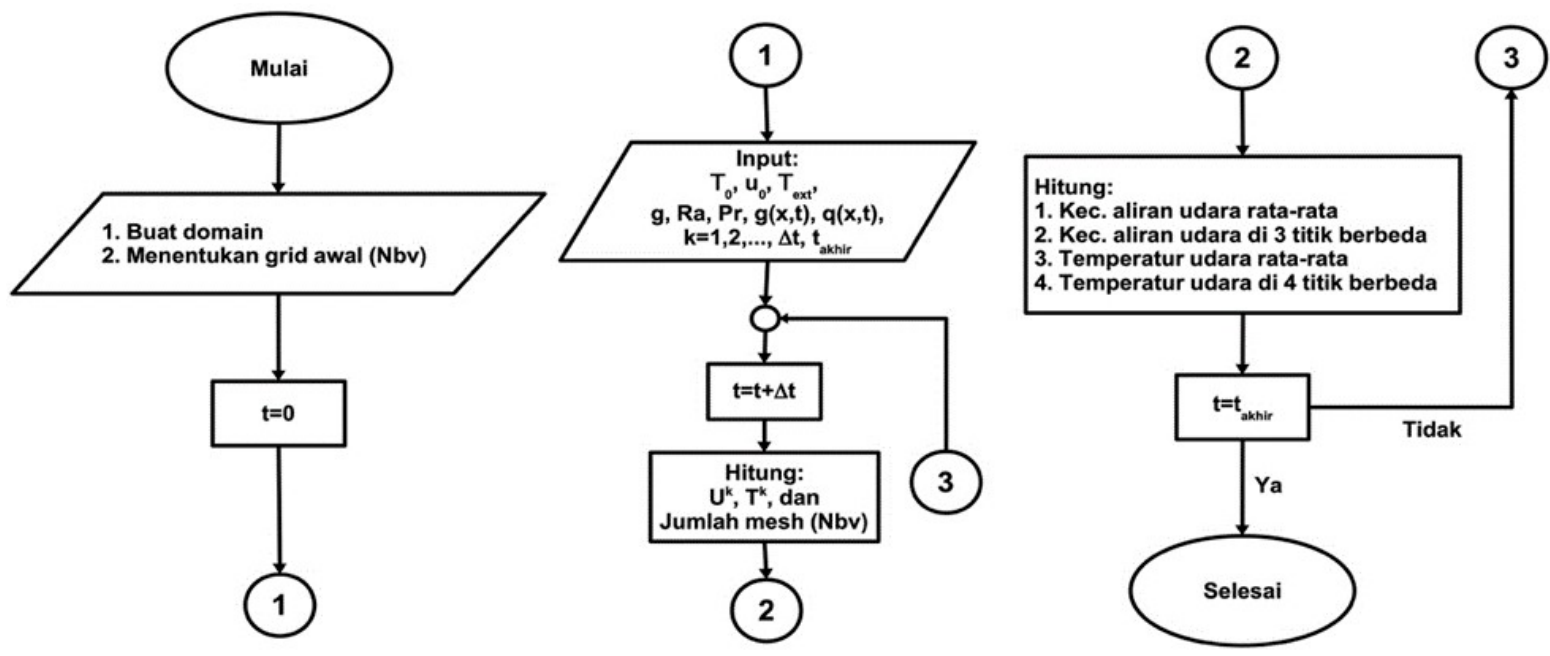

Gambar 4. Ilustrasi diagram alir simulasi aliran udara 


\section{Hasil dan Pembahasan}

Simulasi aliran udara pada kotak konveksi menggunakan Adaptive Finite Element Method sudah dilakukan dengan baik. Beberapa parameter komputasi yang digunakan, seperti; $\Delta t$ dan $t_{\max }$, yakni $10^{-3}$ dan $10^{3}$. Adapun nilai $g(\mathrm{x})=100^{\circ} \mathrm{C}$ dan $q(\mathrm{x}) \approx 500 \mathrm{~T}^{*}$, nilai 500 dianggap sebagai nilai convective heat transfer coefficients untuk udara [25]. Disini, karena aliran udara pada kotak dianggap seperti proses aliran udara pada proses pendinginan prosesor (processor colling device) maka bilangan Rayleigh dan Prandalt yang digunakan sebesar $10^{6}$ dan 0.7 [23].

Hasil simulasi menunjukan bahwa profil temperatur di setiap titik tabung konveksi berbeda (lihat Gambar 7(a)). Kosentrasi panas tertinggi ditemui pada ujung sumber panas (lilin) dan nilai terendah berada pada kedua ujung tabung. Walaupun temperatur di kedua ujung tabung sama, namun nilai temperatur menuju ke bawah tabung (secara vertical) berbeda. Pada tabung sisi kiri, kenaikan temperaturnya lebih lambat dibandingkan dengan tabung sisi kanan. Ini dipengaruhi sumber panas yang berada tepat di bawah tabung sisi kanan, ditambah lagi karena adanya udara masuk yang temperatur rendah ke dalam tabung melalui tabung sisi kiri. Untuk jelasnya dapat dilihat melalui Gambar 5(a). Pada dasarnya, fenomena ini hampir sama dengan fenomena solar chimney, artinya udara panas akan bergerak naik ke lubang (outlet) yang sejajar dengan sumber panas [26]-[28]. Secara fisika, itu disebabkan karena udara panas yang memiliki massa jenis rendah "didesak keluar" oleh udara dingin yang bermassa jenis lebih berat.
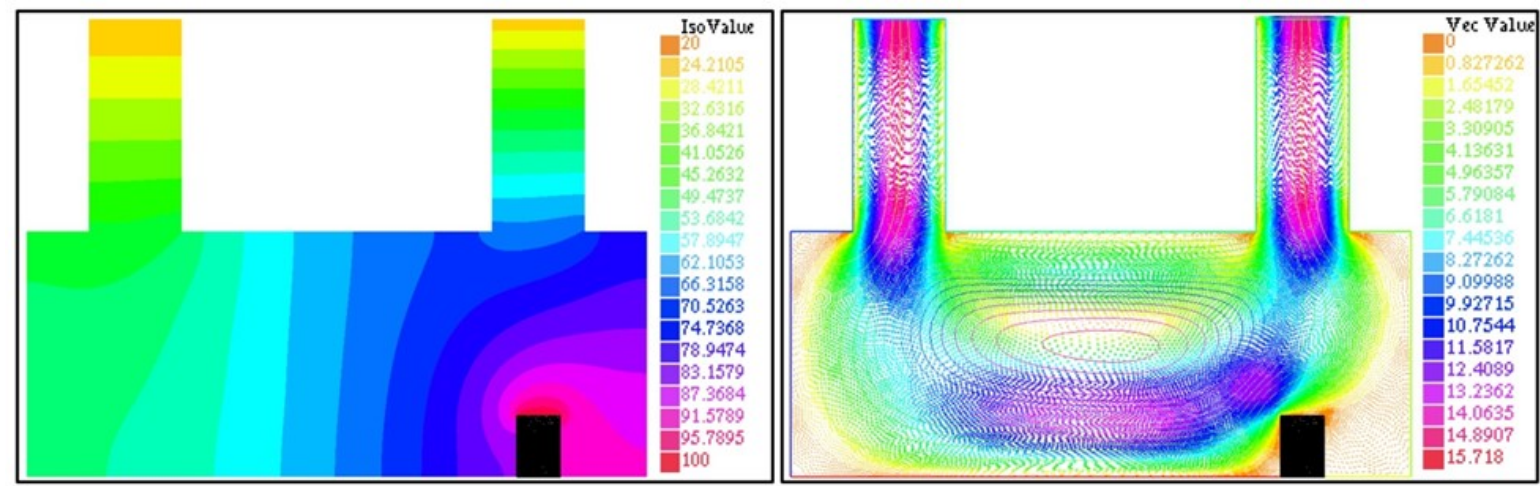

Gambar 5. Ilustrasi; (kiri) aliran panas dan (kanan) aliran udara pada waktu $t_{\max }$ 
Nilai convective heat transfer coefficients yang cukup besar menyebabkan temperatur di beberapa titik dan temperatur rata-rata kotak konveksi selama proses pemanasan menunjukan kenaikan yang signifikan (drastis) di awal-awal waktu dan sudah stabil pada waktu $\mathrm{t} \geq 0.05$. Hal ini senada dengan penelitian yang telah dilakukan oleh Alptekin, et al. [29].

Pada dasarnya, besar kecepatan aliran udara pada sebuah kotak konveksi udara berbeda-beda, ini seperti yang sudah ditunjukan pada Gambar 5(b). Gambar tersebut menunjukan bahwa kecepatan maximum ditemui pada peristiwa masuk dan keluarnya aliran udara di sekitar tabung.
Disini, gambar itu menunjukan bahwa kecepatan maksimum tersebut sama. Untuk melihat hal itu secara spesifik, itu dapat dilihat melalui Gambar 8(a). Gambar tersebut menunjukan bahwa adanya kesamaan perilaku untuk nilai kecepatan rata-rata aliran fluida yang masuk dan keluar melalui tabung kotak konveksi. Disini, terlihat bahwa perubahan kecepatan rata-rata aliran fluida sangat cepat, kecepatannya sudah mencapai $\overline{\mathrm{u}}_{\mathrm{y}} \approx 10.2$ pada saat $\mathrm{t} \geq 0.06$. Secara teori, kondisi ini dianggap wajar dan inilah yang dianggap memenuhi Conservation Laws untuk fluida kompresibel [31].

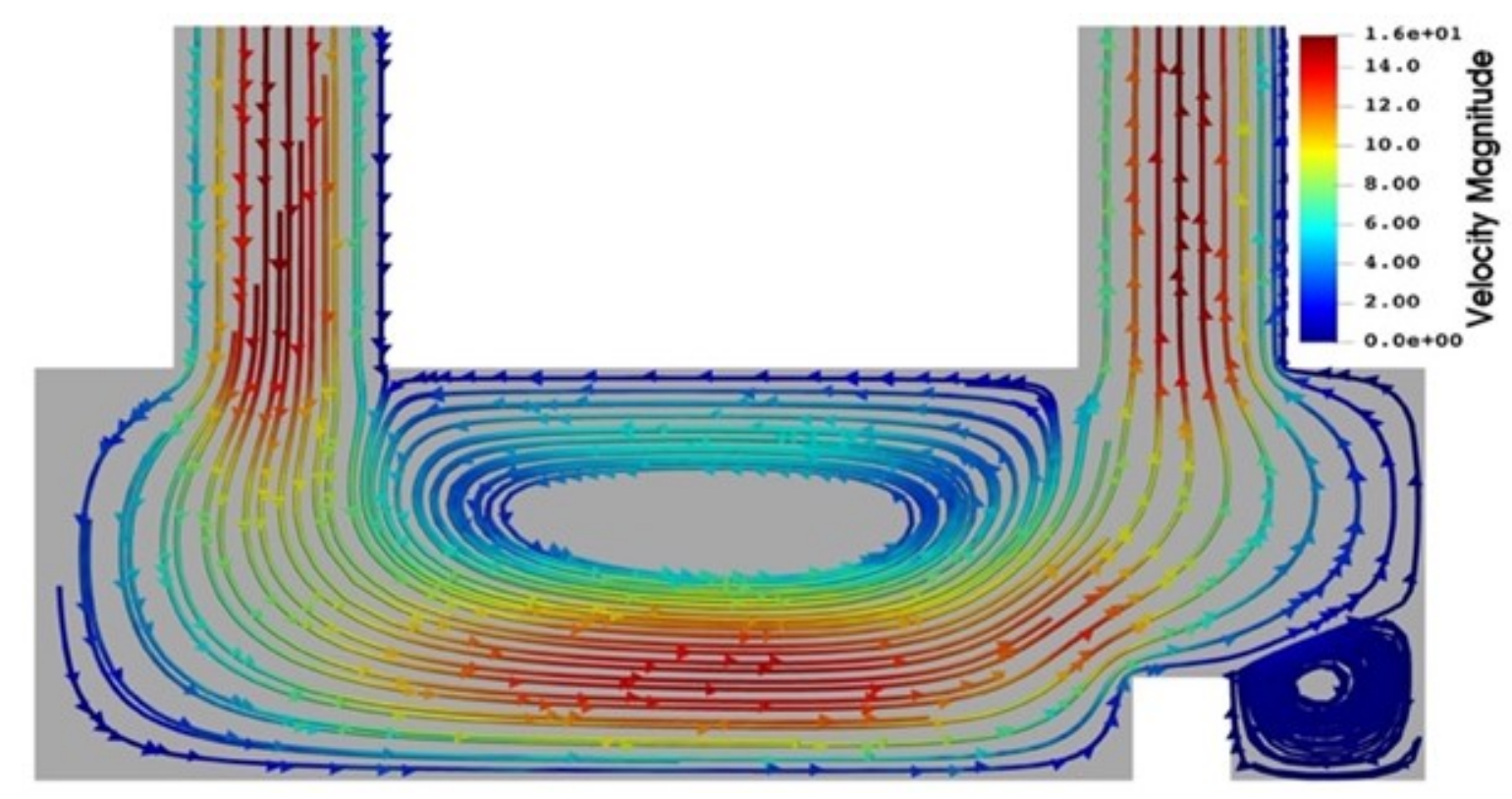

Gambar 6. Streamline aliran udara pada kotak konveksi saat $\mathrm{t}_{\max }$ menggunakan ParaView [30] 

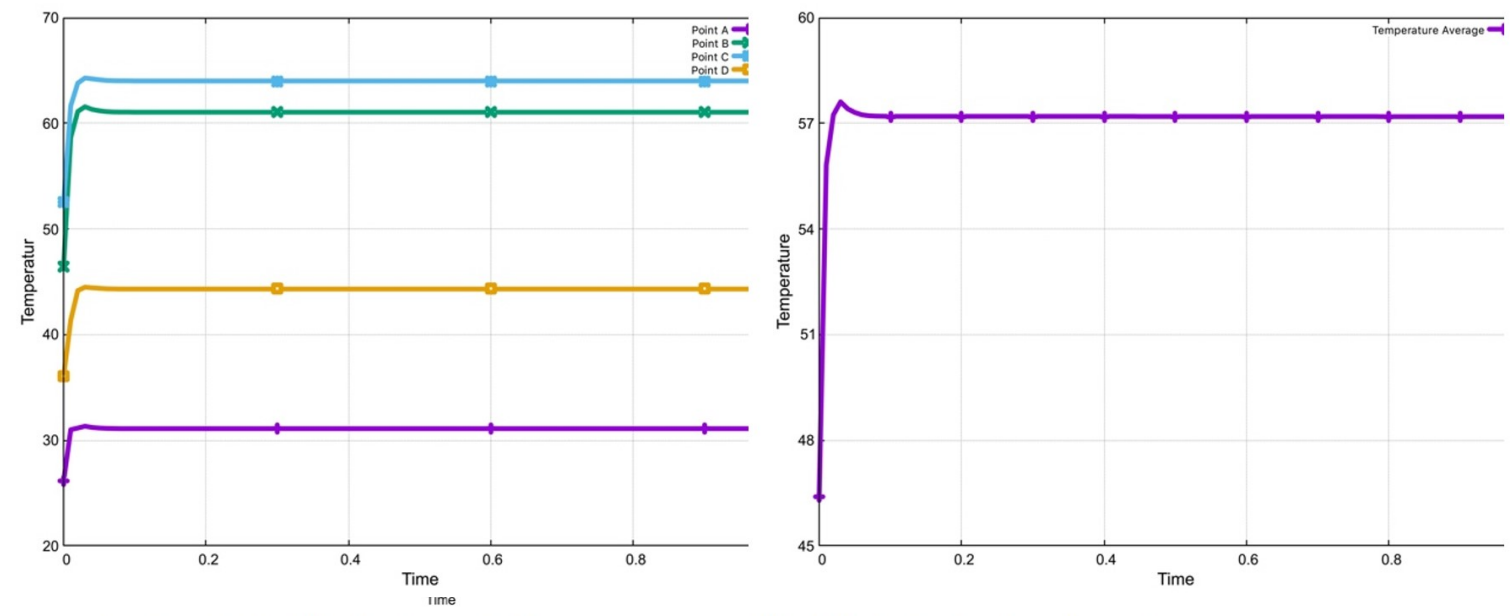

Gambar 7. Profil; (kiri) perubahan temperatur di 4 titik berbeda dan (kanan) temperatur rata-rata $(\overline{\boldsymbol{T}})$ kotak konveksi

Adapun nilai minimum kecepatan aliran udara dijumpai di sekitar sudutsudut kotak. Gambaran umum mengenai kondisi tersebut ditunjukan pada Gambar 5 (b) atau secara spesifik dapat dilihat melalui Gambar 8(b). Dari Gambar 8(b), kecepatan aliran udara cenderung menurun seiring perubahan waktu. Melalui penelitian ini, satu hal yang paling penting dicatat bahwa aliran udara pada kotak konveksi mengalir masuk ke dalam kotak melalui tabung yang berlawanan dari penempatan sumber panas atau lilin (lihat Gambar 6). Hasil ini konsisten dengan ekserimen "STEM Experiment: Gas Convection" [32].
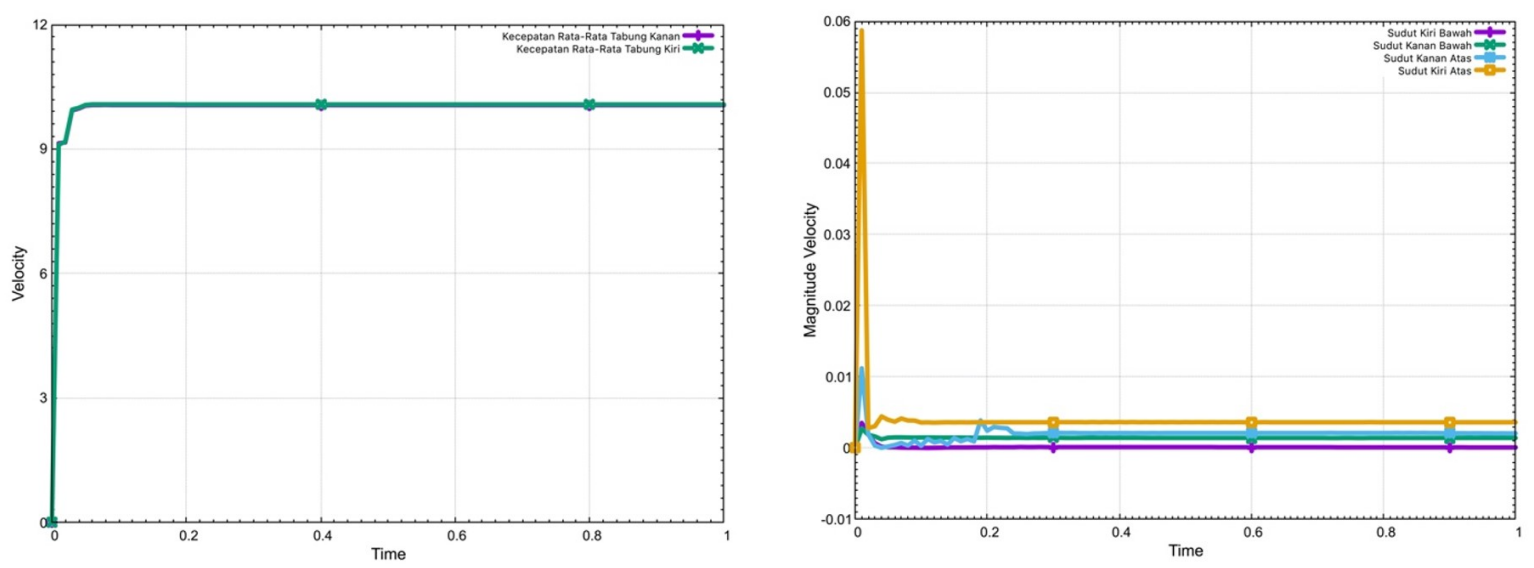

Gambar 8. Profil; (kiri) Kecepatan rata-rata $\left(\overline{\mathrm{u}}_{\mathrm{y}}\right)$ udara masuk dan keluar tabung (kanan) Besar kecepatan aliran udara di berbagai sudut kotak konveksi. 


\section{Simpulan}

Penelitian mengenai aliran udara pada kotak konveksi menggunakan Adaptive Finite Element Method sudah dilakukan dengan baik. Beberapa hal yang menjadi catatan penting setelah melakukan studi ini sebagai berikut; (1) profil temperatur berbeda di setiap titik pada kotak konveksi, temperatur tertinggi dijumpai di sekitar sumber panas dan terendah berada di permukaan ujung tabung. (2) Aliran udara masuk melalui sisi kiri tabung dan ke luar melalui sisi kanan tabung. Kondisi ini menyebabkan kecepatan rata-rata di kedua tabung tersebut sama. Konsekuensi lainnya adalah temperatur kotak konveksi tidak akan homogen atau sama.

\section{Ucapan Terima Kasih}

Ucapan terima kasih disampaikan kepada Pimpinan Universitas Halu Oleo yang telah mendukung penelitian ini. Juga, kepada Prof. Masato Kimura, Kanazawa University, yang sudah memperkenalkan metode ini kepada penulis.

\section{Referensi}

1. A. P. Sturman, "Thermal influences on airflow in mountainous terrain," Progress in Physical Geography, 1987, doi: 10.1177/030913338701100202.

2. G. T. Bitsuamlak, T. Stathopoulos, and C. Bédard, "Numerical evaluation of wind flow over complex terrain: Review," Journal of Aerospace
Engineering. 2004, doi: 10.1061/ (ASCE)0893-1321(2004)17:4(135).

3. T. Nitis, D. Kitsiou, Z. B. Klaić, M. T. Prtenjak, and N. Moussiopoulos, "The effects of basic flow and topography on the development of the sea breeze over a complex coastal environment," Quarterly Journal of the Royal Met. Society, 2005, doi: 10.1256/qj.04.42.

4. G. Qian, Z. Dong, W. Luo, and J. Lu, "Mean airflow patterns upwind of topographic obstacles and their implications for the formation of echo dunes: A wind tunnel simulation of the effects of windward slope," Journal of Geo. Research: Earth Surface, 2011, doi: 10.1029/2011JF002020.

5. K. Niachou, I. Livada, and $M$. Santamouris, "Experimental study of temperature and airflow distribution inside an urban street canyon during hot summer weather conditions. Part II: Airflow analysis," Building and Environment, 2008, doi: 10.1016/ j.buildenv.2007.01.040.

6. J. Avison, Physics for CXC. United Kingdom: Thomas Nelson and Sons Ltd, 1999.

7. J. J. Niemela, L. Skrbek, K. R. Sreenivasan, and R. J. Donnelly, "The wind in confined thermal convection," Journal of Fluid Mechanics, 2001, doi: 10.1017/S0022112001006310.

8. M. Tabata and A. Suzuki, "Mathematical Modeling and Numerical Simulation of Earth's 
Mantle Convection," 2002.

9. Y. Jiang, D. Alexander, H. Jenkins, R. Arthur, and Q. Chen, "Natural ventilation in buildings: Measurement in a wind tunnel and numerical simulation with large-eddy simulation," Journal of Wind Engineering and Industrial Aerodynamics, 2003, doi: 10.1016/ S0167-6105(02)00380-X.

10. S. Murakami, A. Mochida, and K. Hibi, "Three-dimensional numerical simulation of air flow around a cubic model by means of large eddy simulation," Journal of Wind Eng. and Industrial Aerodynamics, 1987, doi: 10.1016/0167 -6105(87)90023-7.

11. T. Uchida and Y. Ohya, "Large-eddy simulation of turbulent airflow over complex terrain," Journal of Wind Eng. and Industrial Aerodynamics, 2003, doi: 10.1016/S0167-6105(02)00347-1.

12. K. Keyhani, P. W. Scherer, and M. M. Mozell, "Numerical simulation of airflow in the human nasal cavity," Journal of Biomechanical Engineering, 1995, doi: 10.1115/1.2794204.

13. F. D. Molina-Aiz, H. Fatnassi, T. Boulard, J. C. Roy, and D. L. Valera, "Comparison of finite element and finite volume methods for simulation of natural ventilation in greenhouses," Computers and Electronics in Agriculture, 2010, doi: 10.1016/ j.compag.2010.03.002.

14. S. J. Yang and W. S. Fu, "A numerical investigation of effects of a moving operator on airflow patterns in a cleanroom," Building and Environment, 2002, doi: 10.1016/ S0360-1323(01)00080-4.

15. O. Laguerre, $\mathrm{S}$. ben Amara, J. Moureh, and D. Flick, "Numerical simulation of air flow and heat transfer in domestic refrigerators," $J$. of Food Eng., 2007, doi: 10.1016/ j.jfoodeng.2006.10.029.

16. H. Sajjadi, M. Salmanzadeh, G. Ahmadi, and S. Jafari, "Simulations of indoor airflow and particle dispersion and deposition by the lattice Boltzmann method using LES and RANS approaches," Building and Environment, 2016, doi: 10.1016/ j.buildenv.2016.03.006.

17. C. Vivian, Science Experiments and Amusements for Children. New York: Dover Publications, 1967.

18. I. Babuvška and W. C. Rheinboldt, "Error Estimates for Adaptive Finite Element Computations," SIAM Journal on Numerical Analysis, 1978, doi: 10.1137/0715049.

19. L. Chen and J. Xu, "Stability and accuracy of adapted finite element methods for singularly perturbed problems," Numerische Mathematik, 2008, doi: 10.1007/s00211-007-01186.

20. N. Roquet and P. Saramito, "An a daptive finite element method for Bingham fluid flows around a cylinder," Computer Methods in 
Applied Mechanics and Engineering, 2003, doi: 10.1016/S0045-7825(03) 00262-7.

21. W. Cao, W. Huang, and R. D. Russell, "An r-Adaptive Finite Element Method Based upon Moving Mesh PDEs," Journal of Computational Physics, 1999, doi: 10.1006/jcph.1998.6151.

22. K. Key and J. Ovall, "A parallel goaloriented adaptive finite element method for 2.5-D electromagnetic modelling," Geophysical Journal Int., 2011, doi: 10.1111/j.1365-246X.2011.05025.x.

23. F. Chillà and J. Schumacher, "New perspectives in turbulent Rayleigh-Bénard convection," European Physical Journal E, vol. 35, no. 7, Jul. 2012, doi: 10.1140/epje/i2012-12058-1.

24. F. Hecht, "New development in freefem+," Journal of Num. Math., 2012, doi: 10.1515/jnum-2012-0013.

25. Engineering ToolBox, "Convective Heat Transfer," 2003. https:// www.engineeringtoolbox.com/ convective-heat-transfer-d_430.html (accessed Sep. 13, 2020).

26. F. Salata, C. Alippi, A. Tarsitano, I. Golasi, and M. Coppi, “A first approach to natural thermoventilation of residential buildings through ventilation chimneys supplied by solar ponds," Sustainability (Switzerland), 2015, doi: 10.3390/ su7079649.

27. M. Coppi, A. Quintino, and F. Salata, "Numerical study of a vertical channel heated from below to enhance natural ventilation in a residential building," International Journal of Ventilation, vol. 12, no. 1, pp. 41-49, 2013, doi: 10.1080/14733315.2013.11684001.

28. C. Afonso and A. Oliveira, "Solar chimneys: Simulation and experiment," Energy and Buildings, vol. 32, no. 1, pp. 71-79, 2000, doi: 10.1016/S03787788(99)00038-9.

29. E. Alptekin, M. Özer, M. Top, F. E. Yavuz, and M. A. Ezan, "A Numerical Study on Phase Change Inside a Spherical Capsule," in Exergetic, Energetic and Environmental Dimensions, Elsevier Inc., 2018, pp. 613-625.

30. J. Ahrens, B. Geveci, and C. Law, "ParaView: An end-user tool for largedata visualization," in Visualization Handbook, Elsevier Inc., 2005, pp. 717 -731 .

31. G. K. Batchelor, An Introduction to Fluid Dynamics. Cambridge University Press, 2000.

32. L. American Scientific, "STEM Experiment: Gas Convection YouTube," $2018 . \quad \mathrm{https}$ :// www.youtube.com/watch? $\mathrm{v}=\mathrm{Ht} 1 \mathrm{Nmw}$ lWaCo (accessed Sep. 13, 2020). 